\title{
Mechanistic Modeling of the Hepatic Disposition of Estradiol-17 $\beta$-Glucuronide in Sandwich-Cultured Human Hepatocytes
}

\author{
Katsuaki Ito, ${ }^{1} \odot$ Noora Sjöstedt, ${ }^{1}$ and $\odot$ Kim L.R. Brouwer \\ Division of Pharmacotherapy and Experimental Therapeutics, UNC Eshelman School of Pharmacy, University of North Carolina at \\ Chapel Hill, Chapel Hill, North Carolina (K.I., N.S., K.L.R.B.); and DMPK Research Department, Teijin Pharma Limited, Hino, Tokyo, \\ Japan (K.I.)
}

Received July 31, 2019; accepted November 12, 2019

\section{ABSTRACT}

Estradiol-17 $\beta$-glucuronide $\left(E_{2} 17 G\right)$ is an estrogen metabolite that has cholestatic properties. In humans, circulating $E_{2} 17 G$ is transported into hepatocytes by organic anion transporting polypeptides (OATPs) and is excreted into bile by multidrug-resistance associated protein 2 (MRP2). $E_{2} 17 G$ is also a substrate of the basolateral efflux transporters MRP3 and MRP4, which translocate $E_{2} 17 \mathrm{G}$ from hepatocytes to blood. However, the contribution of basolateral efflux to hepatocyte disposition of $E_{2} 17 G$ has not been evaluated previously. To address this question, $E_{2} 17 G$ disposition was studied in sandwich-cultured human hepatocytes and mechanistic modeling was applied to calculate clearance values (mean \pm S.D.) for uptake, intrinsic biliary excretion $\left(\mathrm{CL}_{\text {int,bile }}\right)$ and intrinsic basolateral efflux $\left(C L_{\text {int,BL }}\right)$. The biliary excretion index of $E_{2} 17 \mathrm{G}$ was $45 \% \pm 6 \%$. The $\mathrm{CL}_{\text {int,BL }}$ of $\mathrm{E}_{2} 17 \mathrm{G}[0.18 \pm 0.03(\mathrm{ml} / \mathrm{min}) / \mathrm{g}$ liver) was 1.6-fold higher than $\mathrm{CL}_{\text {int,bile }}[0.11 \pm 0.06(\mathrm{ml} / \mathrm{min}) / \mathrm{g}$ liver]. Simulations were performed to study the effects of increased $\mathrm{CL}_{\text {int,BL }}$ and a concomitant decrease in $\mathrm{CL}_{\text {int,bile }}$ on hepatic $\mathrm{E}_{2} 17 \mathrm{G}$ exposure. Results demonstrated that increased $\mathrm{CL}_{\text {int,BL}}$ can effectively reduce hepatocellular and biliary exposure to this potent cholestatic agent.
Simulations also revealed that basolateral efflux can compensate for impaired biliary excretion and, vice versa, to avoid accumulation of $E_{2} 17 G$ in hepatocytes. However, when both clearance processes are impaired by $90 \%$, hepatocyte $E_{2} 17 G$ exposure increases up to 10 fold. These data highlight the contribution of basolateral efflux transport, in addition to MRP2-mediated biliary excretion, to $E_{2} 17 G$ disposition in human hepatocytes. This elimination route could be important, especially in cases where basolateral efflux is induced, such as cholestasis.

\section{SIGNIFICANCE STATEMENT}

The disposition of the cholestatic estrogen metabolite estradiol$17 \beta$-glucuronide $\left(E_{2} 17 G\right)$ was characterized in sandwich-cultured human hepatocytes. The intrinsic basolateral efflux clearance was estimated to be 1.6-fold higher than the intrinsic biliary excretion clearance, emphasizing the contribution of basolateral elimination in addition to biliary excretion. Simulations highlight how hepatocytes can effectively cope with increased $E_{2} 17 G$ through the regulation of both basolateral and biliary transporters.
Introduction

Estradiol-17 $\beta$-glucuronide $\left(\mathrm{E}_{2} 17 \mathrm{G}\right)$ is a metabolite of estradiol, an estrogen steroid hormone. $\mathrm{E}_{2} 17 \mathrm{G}$ is formed by uridine $5^{\prime}$-diphosphoglucuronosyltransferase-mediated glucuronidation of estradiol, primarily

This work was supported by the National Institute of General Medical Sciences of the National Institutes of Health [Award Number R35 GM122576] (K.L.R.B.) and by Teijin Pharma Limited. N.S. was supported by the Sigrid Jusélius Foundation.

${ }^{1}$ K.I. and N.S. contributed equally to this work.

This work was presented, in part, at the AAPS 2018 PharmSci 360 (Washington, DC, November 4-7, 2018).

K.L.R.B. is a co-inventor of the sandwich-cultured hepatocyte technology for quantification of biliary excretion $\left(B-C L E A R^{\odot}\right)$ and related technologies, which have been licensed exclusively to Qualyst Transporter Solutions, recently acquired by BioIVT. B-CLEAR ${ }^{\odot}$ is covered by U.S. patent $6,780,580$ and other U.S. and international patents both issued and pending.

https://doi.org/10.1124/dmd.119.088898. in the liver (Musey et al., 1997; Itäaho et al., 2008). Hepatic concentrations of $\mathrm{E}_{2} 17 \mathrm{G}$ are regulated by multiple transport proteins expressed in the liver. $E_{2} 17 \mathrm{G}$ is a well-known substrate of multidrug-resistance associated protein 2 (MRP2, ABCC2), which mediates $\mathrm{E}_{2} 17 \mathrm{G}$ excretion into bile (Morikawa et al., 2000). On the basolateral (sinusoidal) membrane, organic anion transporting polypeptides 1B1 and 1B3 (OATP1B1, SLCO1B1 and OATP1B3, SLCO1B1) mediate the uptake of $\mathrm{E}_{2} 17 \mathrm{G}$ into hepatocytes from the blood (Karlgren et al., 2012). In fact, $E_{2} 17 G$ is commonly used as a probe substrate in OATP1B1/1B3 and MRP2 inhibition studies in vitro (Pedersen et al., 2008; Karlgren et al., 2012; Brouwer et al., 2013; Morgan et al., 2013). In addition, $\mathrm{E}_{2} 17 \mathrm{G}$ is transported by MRP3 (ABCC3) and MRP4 (ABCC4), which pump substrates from hepatocytes into sinusoidal blood on the basolateral membrane (Zeng et al., 2000; Chen et al., 2001). However, the contribution of basolateral efflux to the hepatic disposition of $\mathrm{E}_{2} 17 \mathrm{G}$ has not been elucidated.

$E_{2} 17 \mathrm{G}$ transport is of interest because it is a potent cholestatic agent and it is postulated to be involved in the pathogenesis of intrahepatic

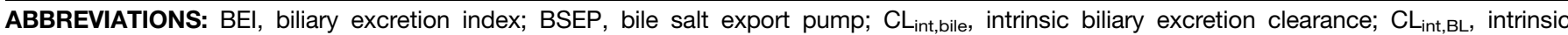

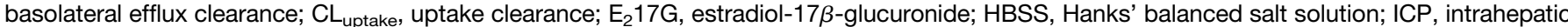
cholestasis of pregnancy; $K_{\text {flux }}$, rate constant for flux from bile into the medium; MRP, multidrug resistance-associated protein; OATP, organic anion transporting polypeptide; $\mathrm{SCHH}$, sandwich-cultured human hepatocytes; TCA, taurocholate. 
cholestasis of pregnancy (ICP). ICP is a condition that is characterized by fairly harmless pruritus and elevated serum bile acid concentrations in the mother, but can increase the risk for preterm labor or even intrauterine death (Geenes and Williamson, 2009). Maternal symptoms typically present in the third trimester of pregnancy, coinciding with the highest estrogen levels during pregnancy. Therefore, it is thought that elevated hepatic $\mathrm{E}_{2} 17 \mathrm{G}$ concentrations may play a role in triggering ICP. Understanding the mechanisms underlying the hepatic disposition of $\mathrm{E}_{2} 17 \mathrm{G}$ is important from the viewpoint of preventing and managing ICP.

Most of the studies regarding the cholestatic effects of $E_{2} 17 \mathrm{G}$ have been performed in rats. $\mathrm{E}_{2} 17 \mathrm{G}$ administration $(2 \mu \mathrm{mol}$ infused over 18 minutes) decreased bile flow by $51 \%$ in perfused rat livers (Huang et al., 2000). Additionally, $\mathrm{E}_{2} 17 \mathrm{G}$ decreased the elimination of the hepatobiliary imaging agent indocyanine green in female rhesus monkeys (Slikker et al., 1983). MRP2 seems to play a key role in $\mathrm{E}_{2} 17 \mathrm{G}$-induced cholestasis, because even doses 12-fold higher than the dose required for cholestatic effects in wild-type rats did not decrease bile flow in Mrp2-deficient $\mathrm{TR}^{-}$rats (Huang et al., 2000). Studies in Mrp2-deficient rats have shown that Mrp2 mediates the secretion of glutathione into bile and that this is important for bile acid-independent bile flow (Takikawa et al., 1991; Elferink and Groen, 2002). Overall, $\mathrm{E}_{2} 17 \mathrm{G}$ appears to exert its cholestatic effects through several mechanisms. Administration of $\mathrm{E}_{2} 17 \mathrm{G}$ to rats increased the internalization of Mrp2 and the bile salt export pump (Bsep) from the cell membrane by clathrin-mediated endocytosis (Mottino et al., 2002; Miszczuk et al., 2018). In addition, $E_{2} 17 G$ increased the accumulation of bile acids through trans-inhibition of BSEP (Stieger et al., 2000; Vallejo et al., 2006). An increase in intrahepatic bile acid concentrations could induce organic solute transporter $\alpha / \beta$ expression (Boyer et al., 2006) and enhance bile acid efflux into the blood, which might explain the observed increase in serum bile acids in ICP (Walker et al., 2002).

Although the current literature suggests a possible role for MRP2 in $\mathrm{E}_{2} 17 \mathrm{G}$-induced ICP, as discussed above, several mechanisms appear to be involved in the development of ICP, and MRP2 is not the only process regulating hepatic $\mathrm{E}_{2} 17 \mathrm{G}$ exposure. The exposure also is affected by hepatic basolateral uptake and efflux transporters. Therefore, in this study, the contribution of basolateral efflux in the hepatic disposition of $\mathrm{E}_{2} 17 \mathrm{G}$ was quantitatively evaluated by uptake and efflux studies using sandwich-cultured human hepatocytes $(\mathrm{SCHH})$ and mechanistic modeling. The clearance estimates derived from the model were used to simulate conditions resulting in inhibition or induction of the different pathways affected by cholestasis or drug-drug interactions based on previously published literature. The results of this study reinforce the notion that basolateral efflux can act as an important excretion route for $\mathrm{E}_{2} 17 \mathrm{G}$, especially in cholestatic conditions where basolateral transporters (e.g., MRP3, MRP4) are upregulated.

\section{Materials and Methods}

Materials. Transporter certified cryopreserved human hepatocytes (three female donors, Table 1) were obtained from ThermoFisher Scientific (Waltham, MA) and In Vitro ADMET Laboratories (Columbia, MD). QualGro ${ }^{\mathrm{TM}}$ seeding medium and QualGro ${ }^{\mathrm{TM}}$ hepatocyte culture medium were obtained from BioIVT (Durham, NC). Tritium-labeled estradiol-17 $\beta$-glucuronide $\left(\left[{ }^{3} \mathrm{H}\right]-\mathrm{E}_{2} 17 \mathrm{G}\right)$ $(52.9 \mathrm{Ci} / \mathrm{mmol}$, radiochemical purity $>97 \%)$ and taurocholate $\left(\left[{ }^{3} \mathrm{H}\right]-\mathrm{TCA}\right)$ $(9.7 \mathrm{Ci} / \mathrm{mmol}$, radiochemical purity $>97 \%)$ were purchased from PerkinElmer (Boston, MA). Nonlabeled $\mathrm{E}_{2} 17 \mathrm{G}$ and TCA were purchased from SigmaAldrich (St. Louis, MO). Standard Hank's balanced salt solution (HBSS) and HBSS without calcium and magnesium were purchased from ThermoFisher Scientific. Collagen (type I)-coated BioCoat ${ }^{\mathrm{TM}}$ 24-well cell culture plates and Matrigel $^{\circledR}$ were obtained from BD Biosciences (San Jose, CA).

Sandwich-Cultured Human Hepatocytes. On day 0, human hepatocytes from the three donors were seeded on BioCoat ${ }^{\mathrm{TM}}$ 24-well plates at a density of
TABLE 1

Donor information for the three hepatocyte lots used in the studies

All donors were women.

\begin{tabular}{lccc}
\hline & Lot 1 & Lot 2 & Lot 3 \\
\hline Race & Caucasian & Caucasian & Caucasian/Hispanic \\
Age $(\mathrm{yr})$ & 37 & 55 & 44 \\
BMI $\left(\mathrm{kg} / \mathrm{m}^{2}\right)$ & 22 & 24 & 29 \\
Cause of death & Head trauma & Stroke & Anoxia, cerebrovascular accident
\end{tabular}

$0.45 \times 10^{6}$ hepatocytes per well using QualGro ${ }^{\mathrm{TM}}$ seeding medium and overlaid with Matrigel ${ }^{\circledR}$ diluted in QualGro ${ }^{\mathrm{TM}}$ hepatocyte culture medium $(0.25 \mathrm{mg} / \mathrm{ml})$ on day 1. SCHH were maintained in QualGro ${ }^{T M}$ hepatocyte culture medium, which was changed daily until experiments were performed on day 5 .

Disposition of $\mathbf{E}_{\mathbf{2}} \mathbf{1 7 G}$ in $\mathbf{S C H H}$. The uptake and efflux studies were conducted by applying B-CLEAR ${ }^{\odot}$ technology (BioIVT) according to the schemes shown in Fig. 1 (Liu et al., 1999). Briefly, SCHH were washed twice and preincubated for 10 minutes at $37^{\circ} \mathrm{C}$ with either standard HBSS (containing calcium and magnesium) or $\mathrm{Ca}^{2+}$-free HBSS (HBSS without calcium and magnesium, supplemented with $1 \mathrm{mM}$ EGTA). After preincubation, the uptake phase was initiated by incubating SCHH with $0.3 \mu \mathrm{M}\left[{ }^{3} \mathrm{H}\right]-\mathrm{E}_{2} 17 \mathrm{G}(2 \mu \mathrm{Ci} / \mathrm{ml})$ in standard $\mathrm{HBSS}$ at $37^{\circ} \mathrm{C}$. $\mathrm{E}_{2} 17 \mathrm{G}$ accumulation in cells and biliary networks (cells + bile; measured in SCHH preincubated with standard HBSS) and $\mathrm{E}_{2} 17 \mathrm{G}$ accumulation in cells (measured in SCHH preincubated with $\mathrm{Ca}^{2+}$-free HBSS) was determined during the uptake phase by terminal sampling at designated time points. After the 10-minute uptake phase, buffers containing $\mathrm{E}_{2} 17 \mathrm{G}$ were removed from the wells and cells were washed three times with $37^{\circ} \mathrm{C}$ standard or $\mathrm{Ca}^{2+}$-free HBSS buffer followed by initiation of the efflux phase. During the efflux phase, $\mathrm{E}_{2} 17 \mathrm{G}$ efflux into the buffer and the amount remaining in cells and biliary networks (standard HBSS preincubation) and cells $\left(\mathrm{Ca}^{2+}\right.$-free HBSS preincubation) were determined by terminal sampling at designated time points. In addition, B-CLEAR ${ }^{\odot}$ studies were performed as above with taurocholate (TCA) for comparison with the $\mathrm{E}_{2} 17 \mathrm{G}$ results. In these studies, $\mathrm{SCHH}$ were incubated with $1 \mu \mathrm{M}$ TCA $(0.8 \mu \mathrm{Ci} / \mathrm{ml})$ for 10 minutes in standard HBSS after a 10-minute preincubation in standard HBSS or $\mathrm{Ca}^{2+}$-free HBSS. Accumulation of TCA in the cells and cells + bile was determined by terminal sampling.

The radioactivity in samples from cells, cells + bile, and buffer was quantified by liquid scintillation counting using a Tri-Carb 3100TR counter (Perkin Elmer). Prior to analysis, cells were lysed with lysis solution containing $1 \times$ phosphatebuffered saline with $0.5 \%$ Triton X-100. Total protein concentration of the cell lysates was determined using the Pierce ${ }^{\mathrm{TM}} \mathrm{BCA}$ Protein Assay Kit (ThermoFisher Scientific). The amount of $E_{2} 17 \mathrm{G}$ and TCA measured in the cell and the buffer samples was normalized to the protein amount in the wells. The biliary excretion index (BEI) was calculated from data at the end of the 10-minute uptake phase using eq. 1:

$$
\mathrm{BEI}(\%)=\frac{\mathrm{X}_{\text {cells }+ \text { bile }}-\mathrm{X}_{\text {cells }}}{\mathrm{X}_{\text {cells }}+\text { bile }} \times 100
$$

where $\mathrm{X}_{\text {cells }+ \text { bile }}$ is the amount of test compound $\left(\mathrm{E}_{2} 17 \mathrm{G}\right.$ or TCA) accumulated in the cells and bile networks in standard HBSS, and $\mathrm{X}_{\text {cells }}$ is the amount of test compound accumulated in the cells that were preincubated in $\mathrm{Ca}^{2+}$-free HBSS.

Mechanistic Modeling of $\mathbf{E}_{\mathbf{2}} \mathbf{1 7 G}$ in SCHH. Mechanistic modeling was applied to the uptake and efflux data using Phoenix WinNonlin, v7.0 (Certara USA, Princeton, NJ) using a previously reported approach (Pfeifer et al., 2013). Briefly, the mechanistic model depicted in Fig. 1 was fit simultaneously to the $\mathrm{E}_{2} 17 \mathrm{G}$ uptake and efflux in standard and $\mathrm{Ca}^{2+}$-free HBSS versus time data. The basolateral uptake clearance $\left(\mathrm{CL}_{\text {uptake }}\right)$, intrinsic basolateral efflux clearance $\left(\mathrm{CL}_{\text {int, } \mathrm{BL}}\right)$, intrinsic biliary excretion clearance $\left(\mathrm{CL}_{\text {int,bile }}\right)$, and the first-order rate constant for flux from the bile network into the buffer $\left(K_{\text {flux }}\right)$ were determined. Assuming non-saturable clearances for all the pathways, the model equations are as follows:

$$
\text { Mass of } \mathrm{E}_{2} 17 \mathrm{G} \text { in standard HBSS }\left(\mathrm{X}_{\text {buffer }}^{+}\right) \text {: }
$$

$\frac{d \mathrm{X}_{\text {buffer }}^{+}}{d t}=\mathrm{C}_{\text {cells }}^{+} \times \mathrm{CL}_{\text {int }, \mathrm{BL}}+\mathrm{X}_{\text {bile }} \times K_{\text {flux }}-\mathrm{C}_{\text {buffer }}^{+} \times \mathrm{CL}_{\text {uptake }}-\mathrm{X}_{\text {buffer }}^{+} \times K_{\text {wash }}$ 
A

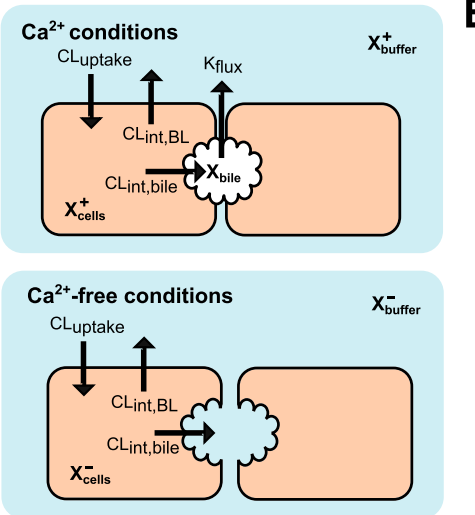

B

STUDY TIMELINE

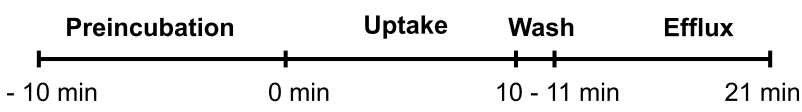

\begin{tabular}{cc|c|c}
$\begin{array}{c}\mathrm{Ca}^{2+} \\
\text { conditions }\end{array}$ & Standard HBSS & $\begin{array}{c}0.3 \mu \mathrm{M} \mathrm{E}_{2} 17 \mathrm{G} \\
\text { in standard HBSS }\end{array}$ & Standard HBSS \\
$\begin{array}{c}\mathrm{Ca}^{2+} \text {-free } \\
\text { conditions }\end{array}$ & $\mathrm{Ca}^{2+}$-free HBSS & $\begin{array}{c}0.3 \mu \mathrm{M} \mathrm{E} \mathrm{E}_{2} 17 \mathrm{G} \\
\text { in standard HBSS }\end{array}$ & $\mathrm{Ca}^{2+}$-free HBSS
\end{tabular}

Fig. 1. Scheme depicting the uptake and efflux studies performed in $\mathrm{SCHH}$ with $\mathrm{E}_{2} 17 \mathrm{G}$. (A) Test compound $\left(\mathrm{E}_{2} 17 \mathrm{G}\right)$ is taken up into the cells via uptake transporters $\left(\mathrm{CL}_{\text {uptake }}\right)$ and excreted from the cell to the medium by transporters on the basolateral membrane $\left(\mathrm{CL}_{\text {int,BL}}\right)$ or into the bile by canalicular transporters $\left(\mathrm{CL}_{\text {int,bile }}\right)$. In the presence of $\mathrm{Ca}^{2+}, \mathrm{E}_{2} 17 \mathrm{G}$ accumulates in the bile canaliculi but can flux into the medium $\left(K_{\text {flux }}\right)$ with contractions of the canaliculi. When incubated in $\mathrm{Ca}^{2+}$-free buffer, the tight junctions of the bile canaliculi are disrupted and all excreted compound returns to the buffer. (B) Summary of the SCHH uptake and efflux study protocol performed in the presence and absence of $\mathrm{Ca}^{2+}$ to determine biliary excretion.

$$
\begin{aligned}
& \text { Mass of } \mathrm{E}_{2} 17 \mathrm{G} \text { in } \mathrm{Ca}^{2+} \text {-free HBSS }\left(\mathrm{X}_{\text {buffer }}^{-}\right) \text {: } \\
& \frac{d \mathrm{X}_{\text {buffer }}^{-}}{d t}=\mathrm{C}_{\text {cells }}^{-} \times \mathrm{CL}_{\text {int,BL }}-\mathrm{C}_{\text {buffer }}^{-} \times \mathrm{CL}_{\text {uptake }}-\mathrm{X}_{\text {buffer }}^{-} \times K_{\text {wash }}+\mathrm{C}_{\text {cells }}^{-} \\
& \quad \times \mathrm{CL}_{\text {int,bile }}
\end{aligned}
$$

Mass of $\mathrm{E}_{2} 17 \mathrm{G}$ in cells $\left(\mathrm{X}_{\text {cells }}\right)$ :

$$
\frac{d \mathrm{X}_{\text {cells }}}{d t}=\mathrm{C}_{\text {buffer }} \times \mathrm{CL}_{\text {uptake }}-\mathrm{C}_{\text {cells }} \times\left(\mathrm{CL}_{\text {int,BL}}+\mathrm{CL}_{\text {int,bile }}\right)
$$

Mass of $\mathrm{E}_{2} 17 \mathrm{G}$ in bile $\left(\mathrm{X}_{\text {bile }}\right)$ :

$$
\frac{d \mathrm{X}_{\text {bile }}}{d t}=\mathrm{C}_{\text {cells }} \times \mathrm{CL}_{\text {int,bile }}-\mathrm{X}_{\text {bile }} \times K_{\text {flux }}
$$

Mass of $\mathrm{E}_{2} 17 \mathrm{G}$ in cells + bile $\left(\mathrm{X}_{\text {cells }}+\right.$ bile $)$ :

$$
\frac{d \mathrm{X}_{\text {cells }}+\text { bile }}{d t}=\frac{\mathrm{X}_{\text {bile }}}{d t}+\frac{\mathrm{X}_{\text {cells }}}{d t}
$$

The first-order rate constant $K_{\text {wash }}$ was fixed at $10^{4}$ minute $^{-1}$ between 10 and 11 minutes in the simulations. This parameter was included to remove all $E_{2} 17 \mathrm{G}$ from the buffer and mimic the wash step between the uptake and efflux phases (Pfeifer et al., 2013; Yang et al., 2015). The initial mass of $\mathrm{E}_{2} 17 \mathrm{G}$ in both buffers was set equal to the dose, and the initial mass in the other compartments was set equal to zero. The in vitro observations used for data fitting were $\mathrm{E}_{2} 17 \mathrm{G} \mathrm{X}_{\text {cells }}+$ bile and $\mathrm{X}_{\text {buffer }}^{+}$in standard HBSS, and $\mathrm{X}_{\text {cells }}$ and $\mathrm{X}_{\text {buffer }}^{-}$in $\mathrm{Ca}^{2+}$-free conditions. An additive error model was used for the mass of $E_{2} 17 \mathrm{G}$ in standard HBSS and in cells incubated in $\mathrm{Ca}^{2+}$-free buffer, and a Poisson error model (a power model with a coefficient of 0.5 ) was used for the other observations. The initial estimate for $\mathrm{CL}_{\text {uptake }}$ was calculated using the first three time points in the uptake phase as $\left(\mathrm{dX}_{\text {cells }+ \text { bile }} / \mathrm{dt}\right) / \mathrm{C}_{\text {buffer }}$. The total efflux clearance $\left(\mathrm{CL}_{\text {int, }} \mathrm{BL}+\mathrm{CL}_{\text {int, bile }}\right)$ was estimated from efflux phase data under $\mathrm{Ca}^{2+}$-free conditions, where $\left(\mathrm{CL}_{\text {int, bile }}+\mathrm{CL}_{\text {int, BL }}\right)=\mathrm{X}_{\mathrm{Buffer}, 21 \mathrm{~min}}^{-} /$area under the curve (AUC) $)_{\text {cells,11-21 min. }}$. Initial estimates were derived by dividing $\mathrm{CL}_{\text {int, bile }}+\mathrm{CL}_{\text {int, } \mathrm{BL}}$ by 2 . The ordinary differential equations were solved using the matrix exponent ordinary differential equations solver in Phoenix WinNonlin. The goodness of fit was evaluated based on visual observation of predicted and observed $\mathrm{E}_{2} 17 \mathrm{G}$ mass and the $\mathrm{CV} \%$ of the derived parameter estimates. The model derived clearance values were scaled to the liver and expressed as milliliter per minute per gram liver, assuming a protein content of $90 \mathrm{mg}$ protein/g liver (Sohlenius-Sternbeck, 2006). The fraction excreted by the two elimination pathways ( $\mathrm{fe}_{\text {bile }}$ and $\mathrm{fe}_{\mathrm{effl}}, \mathrm{BL}$ ) were calculated as the ratio of the specific clearance pathway divided by the sum of both clearance values (Zamek-Gliszczynski et al., 2009).

Effect of Transporter Induction and Inhibition. The effect of transporter induction on $\mathrm{E}_{2} 17 \mathrm{G}$ disposition was evaluated by simulating disposition in $\mathrm{SCHH}$ using the average clearance estimates derived from the mechanistic modeling.
Simulations were performed using Stella version 9 (Isee Systems Inc., Lebanon, $\mathrm{NH}$ ) and eqs. 2-6. $\mathrm{CL}_{\text {int,bile }}$ was decreased and $\mathrm{CL}_{\text {int,BL }}$ was increased by 2- and $4-$ fold in the simulations. These values were chosen to represent plausible changes in protein levels based on available literature (Thakkar et al., 2017). The BEI was calculated for each of the simulations using eq. 1 and simulated $\mathrm{E}_{2} 17 \mathrm{G}$ amounts after 10-minute uptake. Simulations (up to 60 minutes) were performed to evaluate the changes in $E_{2} 17 \mathrm{G}$ in the cells and bile compartments at steady-state due to transporter induction. In addition, the effect of inhibition of $\mathrm{CL}_{\text {int,bile }}$ and/or $\mathrm{CL}_{\text {int,BL }}$ on $\mathrm{E}_{2} 17 \mathrm{G}$ accumulation at steady state was calculated using eq. 7 and varying the clearance values:

$$
K_{\mathrm{p}}=\frac{\mathrm{CL}_{\text {uptake }}}{\mathrm{CL}_{\text {int }, \mathrm{BL}}+\mathrm{CL}_{\text {int,bile }}}
$$

where $K_{p}$ is the hepatocyte to buffer concentration ratio. All data from the simulations and $\mathrm{K}_{\mathrm{p}}$ calculations were normalized to control values (no inhibition or induction).

\section{Results}

All three hepatocyte lots showed time-dependent accumulation of $\mathrm{E}_{2} 17 \mathrm{G}$ into cells during the uptake phase and excretion into the buffer during the efflux phase (Fig. 2). The biliary excretion index (BEI) of $\mathrm{E}_{2} 17 \mathrm{G}$ after 10-minute uptake was $40 \%-52 \%$ in the three lots (Fig. 3). The functionality of the hepatocyte lots was verified with TCA; the BEI of TCA in the same hepatocyte lots was $41 \%-62 \%$. All of the observed time course data for $\mathrm{E}_{2} 17 \mathrm{G}$ uptake and efflux were described adequately by the model, and the CVs of the derived parameters were $\leq 68 \%$. The largest variability in parameter estimates between lots was seen for $\mathrm{CL}_{\text {int,bile }}\left(55 \% \mathrm{CV}\right.$ between lots). The average value of $\mathrm{CL}_{\text {int, BL }}[0.18 \pm$ $0.03(\mathrm{ml} / \mathrm{min}) / \mathrm{g}$ liver) was 1.6 -fold higher than $\mathrm{CL}_{\text {int,bile }}[0.11 \pm 0.06$ $(\mathrm{ml} / \mathrm{min}) / \mathrm{g}$ liver) (Table 2). The average fraction of $\mathrm{E}_{2} 17 \mathrm{G}$ excreted via basolateral efflux (fe efflux,BL$_{\text {, }}$ ) was $62 \%$, and $38 \%$ was excreted via biliary excretion ( $\mathrm{fe}_{\text {bile }}$ ).

Sensitivity analysis revealed that hepatic $\mathrm{E}_{2} 17 \mathrm{G}$ exposure is sensitive to $\mathrm{CL}_{\text {int,BL }}$; a $64 \%$ decrease in hepatic $\mathrm{E}_{2} 17 \mathrm{G}$ exposure was observed when basolateral efflux was increased by fourfold (Fig. 4A). A decrease in $\mathrm{CL}_{\text {int, bile }}$ caused an increase in hepatic $\mathrm{E}_{2} 17 \mathrm{G}$ exposure, especially when $\mathrm{CL}_{\text {int,BL }}$ was unchanged. However, when $\mathrm{CL}_{\text {int,BL }}$ was simultaneously increased fourfold, even a fourfold reduction in $\mathrm{CL}_{\text {int,bile }}$ had minimal effects on $E_{2} 17 \mathrm{G}$ in hepatocytes. $E_{2} 17 \mathrm{G}$ in bile was decreased to a similar extent by a twofold increase in $\mathrm{CL}_{\text {int,BL }}$ and a twofold decrease in $\mathrm{CL}_{\text {int, bile }}$ (Fig. 4B). The same was true for a fourfold increase in $\mathrm{CL}_{\text {int,BL }}$ and a fourfold decrease in $\mathrm{CL}_{\text {int,bile }}$ (Fig. $4 \mathrm{~B}$ ). 

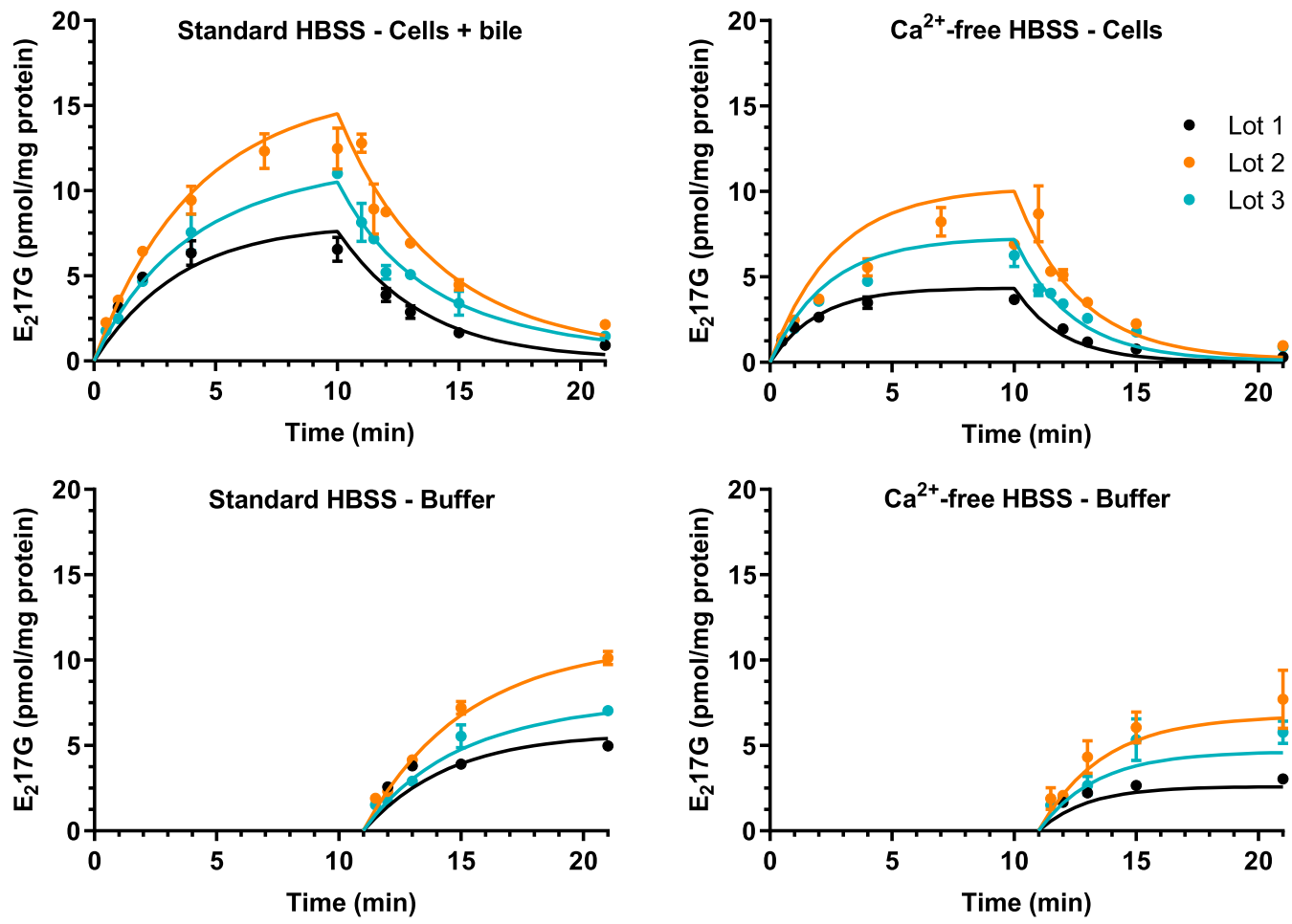

Fig. 2. $\mathrm{E}_{2} 17 \mathrm{G}$ mass (pmol/mg protein) vs. time data in $\mathrm{SCHH}$ during the uptake and efflux phase. SCHH were incubated with $0.3 \mu \mathrm{M}\left[{ }^{3} \mathrm{H}\right]-\mathrm{E}_{2} 17 \mathrm{G}(2 \mu \mathrm{Ci} / \mathrm{ml})$ according to the scheme presented in Fig. 1B. The simulated mass-time profiles were generated using the relevant equations based on the model scheme depicted in Fig. 1A; the final parameter estimates are reported in Table 2. Data are presented as the mean \pm S.D. ( $n=3$ wells, except $n=2$ for cell lysate sample in Lot 1 at 0.5 minute with Ca ${ }^{2+}$-free HBSS).

The maximal simulated decrease in biliary $\mathrm{E}_{2} 17 \mathrm{G}$ was $90 \%$, which was achieved with a fourfold increase in $\mathrm{CL}_{\text {int,BL }}$ and a fourfold decrease in $\mathrm{CL}_{\text {int,bile }}$ (Fig 4B). The BEI was only marginally affected by changes in $\mathrm{CL}_{\text {int,BL}}$; the BEI of $\mathrm{E}_{2} 17 \mathrm{G}$ was decreased more than $30 \%$ when $\mathrm{CL}_{\text {int,bile }}$ was reduced twofold and more than $60 \%$ when $\mathrm{CL}_{\text {int,bile }}$ was reduced fourfold (Fig. 4C).

The results of simulations to evaluate the impact of inhibition of biliary excretion and/or basolateral efflux of $\mathrm{E}_{2} 17 \mathrm{G}$ on hepatic exposure are plotted in Fig. 5. As shown, only modest changes (under twofold) in $\mathrm{E}_{2} 17 \mathrm{G}$ hepatic exposure occurred when $\mathrm{CL}_{\text {int,bile }}$ was inhibited by $90 \%$ because basolateral efflux compensated for impaired biliary excretion. Likewise, $\mathrm{E}_{2} 17 \mathrm{G}$ hepatic exposure increased no more than 2.3 -fold when $\mathrm{CL}_{\text {int,BL }}$ was inhibited by $90 \%$ due to compensation by biliary excretion. However, up to a 10 -fold increase in $\mathrm{E}_{2} 17 \mathrm{G}$ hepatic exposure was observed when both $\mathrm{CL}_{\mathrm{int}, \mathrm{BL}}$ and $\mathrm{CL}_{\mathrm{int} \text {,bile }}$ were inhibited simultaneously up to $90 \%$ of control values.

\section{Discussion}

Understanding hepatic $\mathrm{E}_{2} 17 \mathrm{G}$ disposition is important because $\mathrm{E}_{2} 17 \mathrm{G}$ plays a role in ICP and susceptibility could change if transporter expression is altered by disease or drug interactions. Therefore, this study characterized $\mathrm{E}_{2} 17 \mathrm{G}$ disposition in $\mathrm{SCHH}$ using the uptake and efflux protocol and mechanistic modeling previously established (Pfeifer et al., 2013) to estimate basolateral uptake and efflux clearance values and biliary excretion clearance. These values were used to study the relative contribution of the different pathways and simulate effects of cholestasis-mediated transporter alterations or drug-drug interactions on hepatic $\mathrm{E}_{2} 17 \mathrm{G}$ disposition.

The biliary excretion of $E_{2} 17 \mathrm{G}$ by Mrp2 is well documented (Huang et al., 2000; Morikawa et al., 2000). The influence of biliary excretion on $\mathrm{E}_{2} 17 \mathrm{G}$ disposition in $\mathrm{SCHH}$ is indicated by the $\mathrm{BEI}$, which ranged from
$40 \%$ to $52 \%$ in the three hepatocyte lots. This BEI range for $\mathrm{E}_{2} 17 \mathrm{G}$ agrees with previously published values of $32 \%-43 \%$ (Bi et al., 2006; Lee et al., 2010). The mean $\mathrm{E}_{2} 17 \mathrm{G} \mathrm{CL_{ \text {int,bile } }}$ estimate determined here [0.11 ( $\mathrm{ml} / \mathrm{min}) / \mathrm{g}$ liver] was similar to TCA $\mathrm{CL}_{\text {int,bile }}[0.14(\mathrm{ml} / \mathrm{min}) / \mathrm{g}$ liver] determined previously (Yang et al., 2015). Whereas TCA is predominantly excreted into bile in SCHH (Yang et al., 2015), this is not the case for $\mathrm{E}_{2} 17 \mathrm{G}$. The $\mathrm{CL}_{\text {int,BL }}$ of TCA is 3.3-fold lower than $\mathrm{CL}_{\text {int,bile }}$ (Yang et al., 2015). In contrast, based on our results, the $\mathrm{CL}_{\mathrm{int}, \mathrm{BL}}$ of $\mathrm{E}_{2} 17 \mathrm{G}$ is 1.6 -fold higher than $\mathrm{CL}_{\text {int,bile }}$ (Table 2). Thus, basolateral efflux is an important route of $\mathrm{E}_{2} 17 \mathrm{G}$ elimination in SCHH. It should be noted that there is inter-donor variability in the ratio of $\mathrm{CL}_{\mathrm{int}, \mathrm{BL}}$ to $\mathrm{CL}_{\text {int,bile; }}$; the ratio is $0.9,2.0$, and 2.9 in hepatocyte Lots 1,2 , and 3, respectively (Table 2). This variability is expected based on large individual differences in protein levels of hepatic efflux transporters. For example, MRP2 and MRP3 protein expression showed 6.6- and 3.7-fold individual differences, respectively, in human liver tissue from more than 50 donors (Deo et al., 2012; Wang et al., 2015).

At the basolateral membranes of hepatocytes, MRP3 and MRP4 transport substrates from the cells to the sinusoidal blood (Chandra and Brouwer, 2004). Although our data cannot identify the transporters responsible for the basolateral efflux of $\mathrm{E}_{2} 17 \mathrm{G}$, it is likely to be mediated by MRP3 and/or MRP4, because $\mathrm{E}_{2} 17 \mathrm{G}$ is a well-established substrate for these efflux transporters (Zeng et al., 2000; Chen et al., 2001). MRP3 and MRP4 have comparable $\mathrm{K}_{\mathrm{m}}$ values for $\mathrm{E}_{2} 17 \mathrm{G}$ (Zeng et al., 2000; Chen et al., 2001; Zamek-Gliszczynski et al., 2006). However, in human liver tissue, the absolute protein level of MRP3 is at least 40-fold higher than MRP4 (Vildhede et al., 2015). Thus, MRP3 is assumed to be the primary transporter mediating the hepatic basolateral efflux of $E_{2} 17 G$ in healthy subjects. It should be noted that $E_{2} 17 G$ is not a substrate of organic solute transporter $\alpha / \beta$, which also is expressed on the basolateral membranes of hepatocytes (Malinen et al., 2018). 

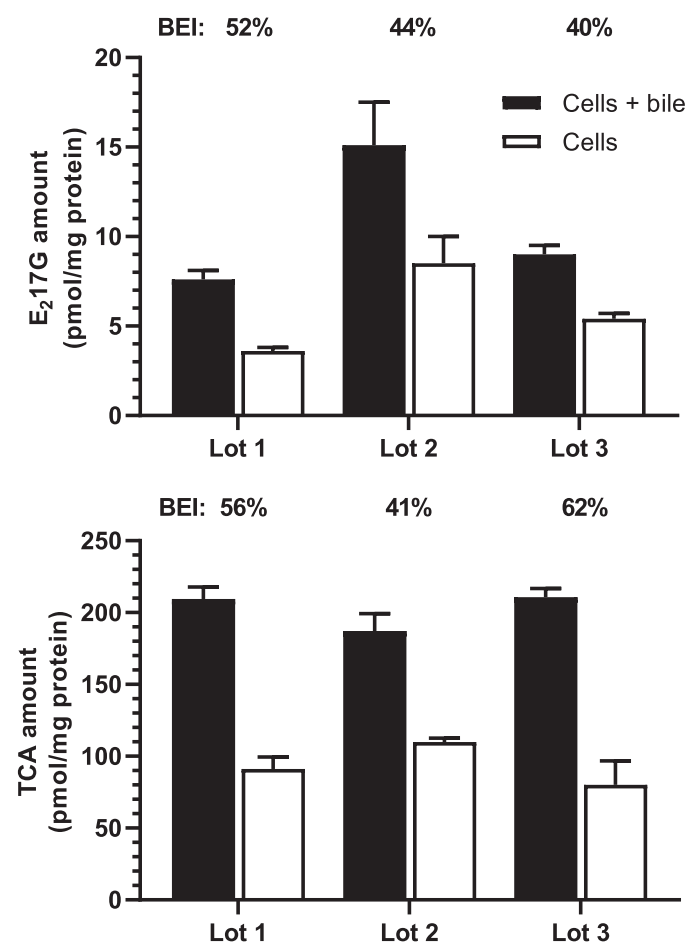

Fig. 3. Biliary excretion of $\mathrm{E}_{2} 17 \mathrm{G}$ and TCA in SCHH. Accumulation (mean \pm S.D.; $n=3$ ) of substrate in SCHH after incubation with $0.3 \mu \mathrm{M}\left[{ }^{3} \mathrm{H}\right]-\mathrm{E}_{2} 17 \mathrm{G}$ $(0.7 \mu \mathrm{Ci} / \mathrm{ml})$ or $1 \mu \mathrm{M}\left[{ }^{3} \mathrm{H}\right]-\mathrm{TCA}(0.8 \mu \mathrm{Ci} / \mathrm{ml})$ for 10 minutes in standard HBSS after a 10-minute preincubation in standard HBSS (black bars; cells + bile) or $\mathrm{Ca}^{2+}$-free HBSS (white bars; cells). The BEI was calculated according to eq. 1 .

The contribution of basolateral efflux to $\mathrm{E}_{2} 17 \mathrm{G}$ elimination from hepatocytes could be amplified in situations where basolateral efflux transporter levels are increased. Basolateral transporters can be induced in several liver diseases, including cholestasis (Thakkar et al., 2017). For example, MRP3 protein levels increased 4.6-fold in patients with obstructive cholestasis caused by gall stones (Chai et al., 2012) and increased 2.1- to 2.6-fold in patients with stage III/IV primary biliary cirrhosis (Zollner et al., 2003). A similar increase compared with control subjects was reported for MRP4 in obstructive cholestasis (3.1-fold) and primary biliary cirrhosis (3.2- to 3.5-fold) (Zollner et al., 2007; Chai et al., 2011). MRP3 and MRP4 protein levels also are increased in nonalcoholic steatohepatitis (Hardwick et al., 2011). In addition, Mrp3/ MRP3 is upregulated in Mrp2-deficient $\mathrm{TR}^{-}$rats and in patients with Dubin-Johnson syndrome (König et al., 1999; Johnson et al., 2006). In contrast, MRP2 levels do not appear to be changed in cholestasis in humans, but some studies point to a mislocalization of MRP2 in cholestatic disease (Zollner et al., 2001, 2003; Kojima et al., 2003; Chai et al., 2012).

A sensitivity analysis was performed to evaluate the effects of changes in efflux protein levels on hepatic $\mathrm{E}_{2} 17 \mathrm{G}$ disposition. The analysis revealed that hepatic $\mathrm{E}_{2} 17 \mathrm{G}$ was sensitive to $\mathrm{CL}_{\mathrm{int}, \mathrm{BL}}$; a fourfold increase in $\mathrm{CL}_{\text {int,BL }}$ decreased hepatic $\mathrm{E}_{2} 17 \mathrm{G}$ by $64 \%$ (Fig. $4 \mathrm{~A}$ ). Biliary $\mathrm{E}_{2} 17 \mathrm{G}$ also was examined because $\mathrm{E}_{2} 17 \mathrm{G}$ in bile may play a role in the development of cholestasis through trans-inhibition of BSEP (Stieger et al., 2000). Biliary $E_{2} 17 G$ was influenced by both basolateral and biliary transporters (Fig. 4B). Sensitivity analysis of $\mathrm{CL}_{\text {int,bile }}$ revealed that a decrease in $\mathrm{CL}_{\text {int, bile }}$ (e.g., MRP2 downregulation) effectively decreased the amount of $\mathrm{E}_{2} 17 \mathrm{G}$ in bile (Fig. 4B). However, the effects on $\mathrm{E}_{2} 17 \mathrm{G}$ accumulation in hepatocytes were smaller (Fig. 4A). Importantly, decreased $\mathrm{CL}_{\text {int,bile }}$ caused only a minimal increase in cellular $\mathrm{E}_{2} 17 \mathrm{G}$ amounts when $\mathrm{CL}_{\mathrm{int}, \mathrm{BL}}$ was induced fourfold (Fig. 4A). These results suggest that induction of basolateral efflux transporters (e.g., MRP3 and MRP4) in cholestasis could lower the amount of $E_{2} 17 \mathrm{G}$ in hepatocytes, even when biliary clearance is impaired, and may help relieve cholestasis. Pregnant women with defects in these compensatory mechanisms could be predisposed to developing ICP.

The inhibition of MRP3 and MRP4 is a risk factor for drug-induced cholestasis (Morgan et al., 2013; Köck et al., 2014; Chan and Benet, 2018). In addition, MRP2 inhibition alongside possible mislocalization in cholestasis can disturb hepatocellular homeostasis of MRP2 substrates. As expected, our simulations revealed that inhibition of either $\mathrm{CL}_{\text {int,BL }}$ alone (i.e., MRP3 and MRP4 transport) or inhibition of $\mathrm{CL}_{\text {int, bile }}$ alone (i.e., MRP2 transport) has a minimal effect on hepatic $\mathrm{E}_{2} 17 \mathrm{G}$ exposure (Fig. 5). This is consistent with the concept of fractional excretion (Zamek-Gliszczynski et al., 2009). Based on the calculated clearance estimates in $\mathrm{SCHH}, 62 \%$ of $\mathrm{E}_{2} 17 \mathrm{G}$ is excreted via the basolateral pathway. Therefore, even a complete knockout of this predominant excretion pathway would only increase $\mathrm{E}_{2} 17 \mathrm{G}$ in hepatocytes by a maximum of 2.6-fold, assuming that no changes in the compensatory biliary pathway occurred. However, simulations indicated that hepatic $\mathrm{E}_{2} 17 \mathrm{G}$ was markedly increased with simultaneous inhibition of both pathways (Fig. 5). The simultaneous inhibition of several MRP transporters is a likely event due to overlap in the inhibitor specificity of MRPs (Morgan et al., 2013), and this may predispose patients to $\mathrm{E}_{2} 17 \mathrm{G}$-mediated cholestasis. For example, medications that have been associated with drug-induced liver injury and cholestasis (e.g., repaglinide, cyclosporine A, everolimus) exhibit overlapping inhibition of MRP2, MRP3, and MRP4 (Morgan et al., 2013).

The hepatic clearance estimates of $\mathrm{E}_{2} 17 \mathrm{G}$ were determined assuming linear processes. No saturation of these pathways is expected with the $0.3 \mu \mathrm{M} \mathrm{E}_{2} 17 \mathrm{G}$ dose used in this study. The apparent $K_{\mathrm{m}}$ for the uptake clearance of $\mathrm{E}_{2} 17 \mathrm{G}$ in plated human hepatocytes is reported to be $7.7 \mu \mathrm{M}$ (Liao et al., 2019), and the $K_{\mathrm{m}}$ values of $\mathrm{E}_{2} 17 \mathrm{G}$ for MRP3 and MRP4 are in the range of 20-40 $\mu \mathrm{M}$ determined in vesicle studies (Zeng et al., 2000; Chen et al., 2001; Zamek-Gliszczynski et al., 2006). E 17 G shows cooperative binding and sigmoidal kinetics of MRP2-mediated transport in membrane vesicles with $K_{\mathrm{m}} / K_{0.5}$ values of $>100 \mu \mathrm{M}$ (Herédi-Szabó et al., 2009). The highest hepatocellular concentrations of $\mathrm{E}_{2} 17 \mathrm{G}$ reached in this study were $<1.5 \mu \mathrm{M}$. Therefore, we believe that the assumption of linearity is reasonable. Another simplification of the model was that passive permeability was not modeled as a separate

TABLE 2

Final parameter estimates from the model fitting

\begin{tabular}{|c|c|c|c|c|}
\hline Hepatocyte lot & $\mathrm{CL}_{\text {uptake }}$ & $\mathrm{CL}_{\mathrm{int}, \mathrm{BL}}$ & $\mathrm{CL}_{\text {int,bile }}$ & $K_{\text {flux }}$ \\
\hline & & $(\mathrm{ml} / \mathrm{min}) / \mathrm{g}$ liver $(\mathrm{CV} \%)$ & & $\min ^{-1}(C V \%)$ \\
\hline Lot 1 & $0.69(15 \%)$ & $0.16(68 \%)$ & $0.18(47 \%)$ & $0.31(41 \%)$ \\
\hline Lot 2 & $1.2(9 \%)$ & $0.17(19 \%)$ & $0.083(35 \%)$ & $0.21(22 \%)$ \\
\hline Lot 3 & $0.98(9 \%)$ & $0.21(14 \%)$ & $0.073(28 \%)$ & $0.17(22 \%)$ \\
\hline Mean \pm S.D. & $0.96 \pm 0.26$ & $0.18 \pm 0.03$ & $0.11 \pm 0.06$ & $0.23 \pm 0.07$ \\
\hline
\end{tabular}


A

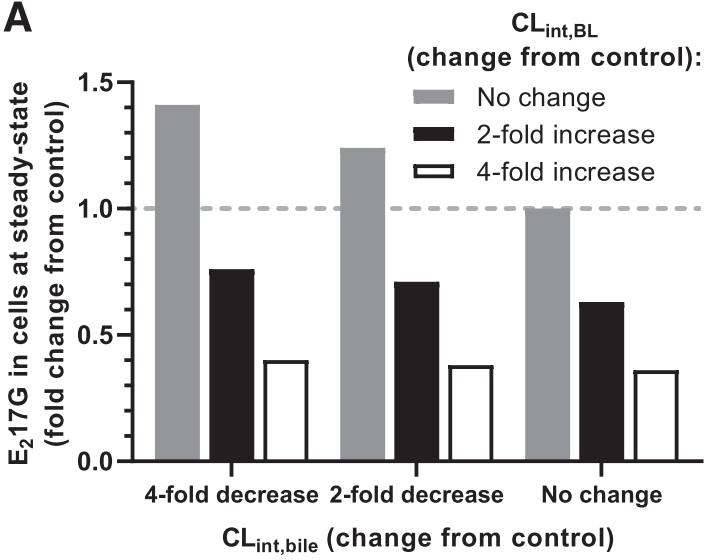

B

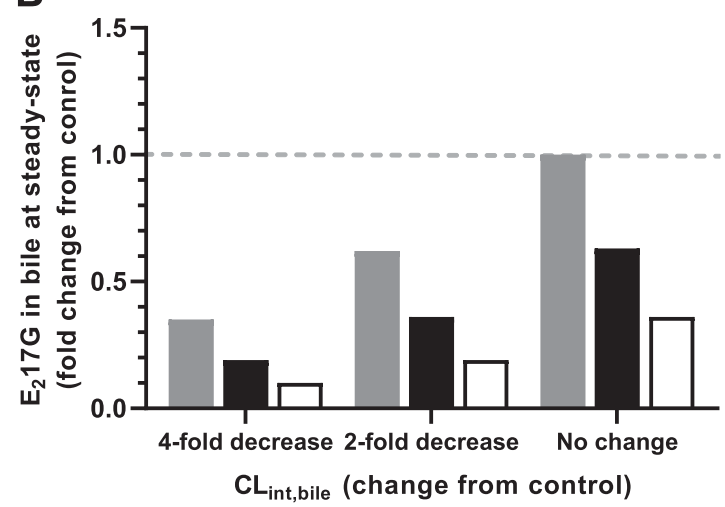

C

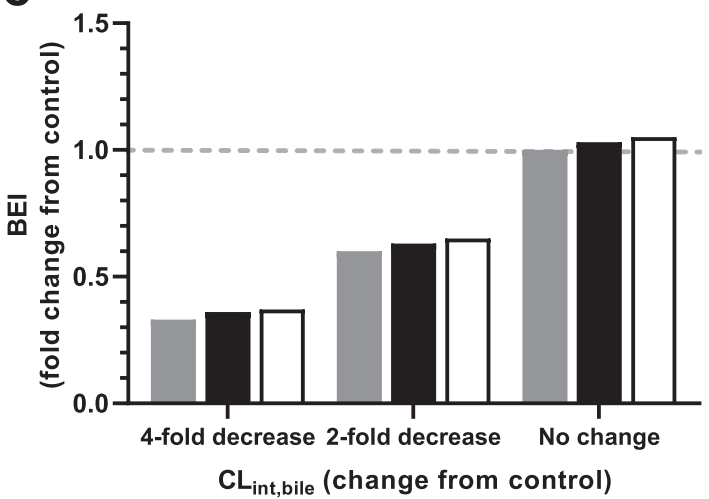

Fig. 4. Effects of alterations in $\mathrm{CL}_{\text {int.BL }}$ and $\mathrm{CL}_{\text {int,bile }}$ on $\mathrm{E}_{2} 17 \mathrm{G}$ disposition in $\mathrm{SCHH}$. The impact of designated fold changes in clearance estimates on mean steady-state levels of $\mathrm{E}_{2} 17 \mathrm{G}$ in cells (A) and bile (B), and on the BEI (C) at 10 minutes are plotted. All values were normalized to control simulations run using the average clearance estimates of $\mathrm{E}_{2} 17 \mathrm{G}$ from the mechanistic modeling.

parameter. However, passive permeability has been shown previously to play a minor role in $\mathrm{E}_{2} 17 \mathrm{G}$ uptake in hepatocytes, with active processes contributing to $89.3 \% \pm 8.1 \%$ of total uptake (Liao et al., 2019). The biliary excretion of $E_{2} 17 \mathrm{G}$ was decreased by more than $75 \%$ in the presence of the MRP2 inhibitor sulindac or its metabolite (Lee et al., 2010), suggesting that passive permeability is also minor in $E_{2} 17 \mathrm{G}$ efflux from hepatocytes.

SCHH continue to be a standard method for assessing hepatic disposition in vitro, particularly regarding transporter-mediated efflux (Brouwer et al., 2013). As bile networks re-form over days in culture, the levels of efflux transporters increase and exhibit appropriate functionality (Swift et al., 2010). An important consideration with this study is that levels of individual transporters in SCHH may differ from those in

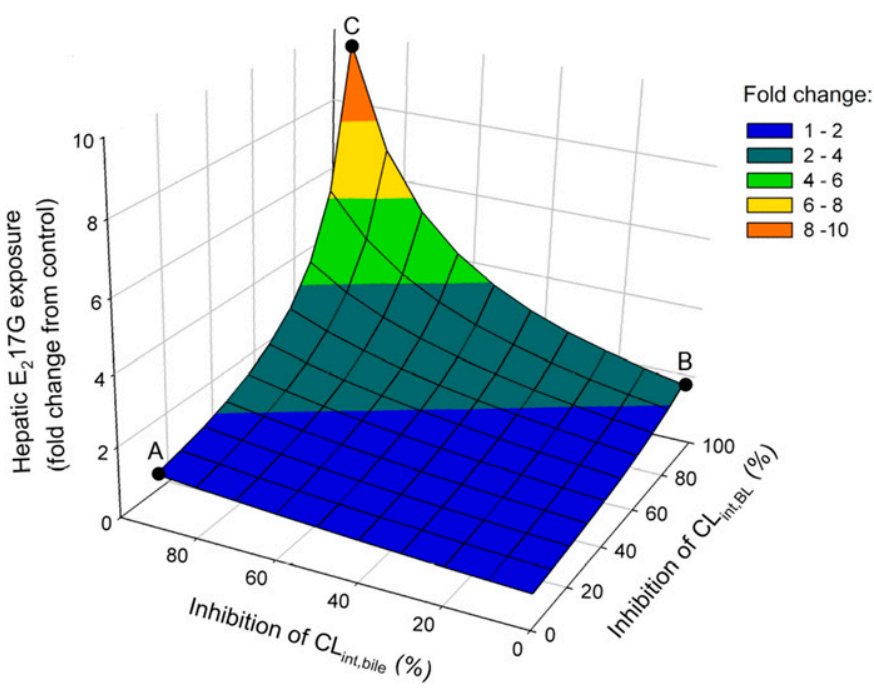

Fig. 5. Effects of $0 \%-90 \%$ efflux inhibition on hepatic $E_{2} 17 \mathrm{G}$ exposure. The hepatocyte to buffer concentration ratio $\left(K_{\mathrm{p}}\right.$, eq. 7) was calculated using average clearance values (control) and decreasing either $\mathrm{CL}_{\mathrm{int}, \mathrm{BL}}$ and/or $\mathrm{CL}_{\text {int,bile. Exposure }}$ is shown as fold change from control (no inhibition). When $\mathrm{CL}_{\text {int,bile }}$ is inhibited by $90 \%$, hepatic $\mathrm{E}_{2} 17 \mathrm{G}$ exposure is 1.5 -fold (point $\mathrm{A}$ ). When $\mathrm{CL}_{\mathrm{int}, \mathrm{BL}}$ is inhibited by $90 \%$, hepatic $\mathrm{E}_{2} 17 \mathrm{G}$ exposure is 2.3 -fold (point $\mathrm{B}$ ). However, when both $\mathrm{CL}_{\text {int,bile }}$ and $\mathrm{CL}_{\text {int, } \mathrm{BL}}$ are inhibited by $90 \%$, the hepatic $\mathrm{E}_{2} 17 \mathrm{G}$ exposure increases 10 -fold (point C).

liver tissue, which could limit the ability to accurately translate data from in vitro to in vivo. Recently, the absolute protein abundance of MRP2 and MRP3, the primary transporters involved in hepatic $\mathrm{E}_{2} 17 \mathrm{G}$ efflux, was reported to be approximately fourfold higher, on average, in SCHH than in liver tissue from corresponding donors (Kumar et al., 2019). However, the ratio of absolute levels of MRP2 to MRP3 was similar in SCHH and liver tissue (Kumar et al., 2019). Although protein abundance was not determined in the current study, the available literature suggests that the relative contribution of the efflux pathways of interest are similar in $\mathrm{SCHH}$ and in liver tissue.

In summary, this study revealed that basolateral efflux in addition to biliary excretion is a significant route of $\mathrm{E}_{2} 17 \mathrm{G}$ elimination in $\mathrm{SCHH}$. The importance of this elimination pathway is further emphasized when basolateral efflux transporter levels (e.g., MRP3 and MRP4) are increased, which may occur in conditions such as cholestasis. The simulations presented here highlight how hepatocytes can effectively cope with increased $E_{2} 17 \mathrm{G}$ through the regulation of both basolateral and biliary transporters.

\section{Acknowledgments}

The authors acknowledge Certara for providing Phoenix software to the UNC Eshelman School of Pharmacy, Division of Pharmacotherapy and Experimental Therapeutics, as part of the Pharsight Academic Center of Excellence Program.

\section{Authorship Contributions}

Participated in research design: Ito, Brouwer

Conducted experiments: Ito, Sjöstedt.

Performed data analysis: Ito, Sjöstedt, Brouwer.

Wrote or contributed to the writing of the manuscript: Sjöstedt, Ito, Brouwer.

\section{References}

Bi YA, Kazolias D, and Duignan DB (2006) Use of cryopreserved human hepatocytes in sandwich culture to measure hepatobiliary transport. Drug Metab Dispos 34:1658-1665.

Boyer JL, Trauner M, Mennone A, Soroka CJ, Cai SY, Moustafa T, Zollner G, Lee JY, and Ballatori N (2006) Upregulation of a basolateral FXR-dependent bile acid efflux transporter OSTalpha-OSTbeta in cholestasis in humans and rodents. Am J Physiol Gastrointest Liver Physiol 290:G1124-G1130. 
Brouwer KLR, Keppler D, Hoffmaster KA, Bow DA, Cheng Y, Lai Y, Palm JE, Stieger B, and Evers R; International Transporter Consortium (2013) In vitro methods to support transporter evaluation in drug discovery and development. Clin Pharmacol Ther 94:95-112.

Chai J, He Y, Cai SY, Jiang Z, Wang H, Li Q, Chen L, Peng Z, He X, Wu X, et al. (2012) Elevated hepatic multidrug resistance-associated protein 3/ATP-binding cassette subfamily $\mathrm{C} 3$ expression in human obstructive cholestasis is mediated through tumor necrosis factor alpha and c-Jun NH2 terminal kinase/stress-activated protein kinase-signaling pathway. Hepatology 55:1485-1494.

Chai J, Luo D, Wu X, Wang H, He Y, Li Q, Zhang Y, Chen L, Peng ZH, Xiao T, et al. (2011) Changes of organic anion transporter MRP4 and related nuclear receptors in human obstructive cholestasis. J Gastrointest Surg 15:996-1004.

Chan R and Benet LZ (2018) Measures of BSEP inhibition in vitro are not useful predictors of DILI. Toxicol Sci 162:499-508.

Chandra P and Brouwer KLR (2004) The complexities of hepatic drug transport: current knowledge and emerging concepts. Pharm Res 21:719-735.

Chen ZS, Lee K, and Kruh GD (2001) Transport of cyclic nucleotides and estradiol 17-beta-Dglucuronide by multidrug resistance protein 4 . Resistance to 6-mercaptopurine and 6thioguanine. J Biol Chem 276:33747-33754

Deo A K, Prasad B, Balogh L, Lai Y, and Unadkat J K (2012) Interindividual Variability in Hepatic Expression of the Multidrug Resistance-Associated Protein 2 (MRP2/ABCC2): Quantification by Liquid Chromatography/Tandem Mass Spectrometry. Drug Metab Dispos 40:852-855.

Elferink RO and Groen AK (2002) Genetic defects in hepatobiliary transport. Biochim Biophys Acta 1586:129-145.

Geenes V and Williamson C (2009) Intrahepatic cholestasis of pregnancy. World J Gastroenterol 15:2049-2066.

Hardwick RN, Fisher CD, Canet MJ, Scheffer GL, and Cherrington NJ (2011) Variations in ATPbinding cassette transporter regulation during the progression of human nonalcoholic fatty liver disease. Drug Metab Dispos 39:2395-2402.

Herédi-Szabó K, Glavinas H, Kis E, Méhn D, Báthori G, Veres Z, Kóbori L, von Richter O, Jemnitz K, and Krajcsi P (2009) Multidrug resistance protein 2-mediated estradiol-17beta-Dglucuronide transport potentiation: in vitro-in vivo correlation and species specificity. Drug Metab Dispos 37:794-801.

Huang L, Smit JW, Meijer DK, and Vore M (2000) Mrp2 is essential for estradiol-17beta(beta-Dglucuronide)-induced cholestasis in rats. Hepatology 32:66-72.

Itäaho K, Mackenzie P I, Ikushiro S, Miners J O, and Finel M (2008) The configuration of the 17 hydroxy group variably influences the glucuronidation of beta-estradiol and epiestradiol by human UDP-glucuronosyltransferases. Drug Metab Dispos 36:2307-2315.

Johnson BM, Zhang P, Schuetz JD, and Brouwer KLR (2006) Characterization of transport protein expression in multidrug resistance-associated protein (Mrp) 2-deficient rats. Drug Metab Dispos 34:556-562.

Karlgren M, Vildhede A, Norinder U, Wisniewski JR, Kimoto E, Lai Y, Haglund U, and Artursson P (2012) Classification of inhibitors of hepatic organic anion transporting polypeptides (OATPs): influence of protein expression on drug-drug interactions. J Med Chem 55:4740-4763.

Köck K, Ferslew BC, Netterberg I, Yang K, Urban TJ, Swaan PW, Stewart PW, and Brouwer KLR (2014) Risk factors for development of cholestatic drug-induced liver injury: inhibition of hepatic basolateral bile acid transporters multidrug resistance-associated proteins 3 and 4 . Drug Metab Dispos 42:665-674.

Kojima H, Nies AT, König J, Hagmann W, Spring H, Uemura M, Fukui H, and Keppler D (2003) Changes in the expression and localization of hepatocellular transporters and radixin in primary biliary cirrhosis. J Hepatol 39:693-702.

König J, Rost D, Cui Y, and Keppler D (1999) Characterization of the human multidrug resistance protein isoform MRP3 localized to the basolateral hepatocyte membrane. Hepatology 29: $1156-1163$.

Kumar V, Salphati L, Hop CECA, Xiao G, Lai Y, Mathias A, Chu X, Humphreys WG, Liao M, Heyward S, et al. (2019) A comparison of total and plasma membrane abundance of transporters in suspended, plated, sandwich-cultured human hepatocytes versus human liver tissue using quantitative targeted proteomics and cell surface biotinylation. Drug Metab Dispos 47:350-357.

Lee JK, Paine MF, and Brouwer KLR (2010) Sulindac and its metabolites inhibit multiple transport proteins in rat and human hepatocytes. J Pharmacol Exp Ther 334:410-418.

Liao M, Zhu Q, Zhu A, Gemski C, Ma B, Guan E, Li AP, Xiao G, and Xia CQ (2019) Comparison of uptake transporter functions in hepatocytes in different species to determine the optimal model for evaluating drug transporter activities in humans. Xenobiotica 49:852-862.

Liu X, LeCluyse EL, Brouwer KR, Lightfoot RM, Lee JI, and Brouwer KLR (1999) Use of $\mathrm{Ca}^{2+}$ modulation to evaluate biliary excretion in sandwich-cultured rat hepatocytes. $J$ Pharmacol Exp Ther 289:1592-1599.

Malinen MM, Ali I, Bezençon J, Beaudoin JJ, and Brouwer KLR (2018) Organic solute transporter $\mathrm{OST} \alpha / \beta$ is overexpressed in nonalcoholic steatohepatitis and modulated by drugs associated with liver injury. Am J Physiol Gastrointest Liver Physiol 314:G597-G609.

Miszczuk GS, Barosso IR, Larocca MC, Marrone J, Marinelli RA, Boaglio AC, Sánchez Pozzi EJ, Roma MG, and Crocenzi FA (2018) Mechanisms of canalicular transporter endocytosis in the cholestatic rat liver. Biochim Biophys Acta Mol Basis Dis 1864 (4 Pt A):1072-1085.
Morgan RE, van Staden CJ, Chen Y, Kalyanaraman N, Kalanzi J, Dunn RT II, Afshari CA, and Hamadeh HK (2013) A multifactorial approach to hepatobiliary transporter assessment enables improved therapeutic compound development. Toxicol Sci 136:216-241.

Morikawa A, Goto Y, Suzuki H, Hirohashi T, and Sugiyama Y (2000) Biliary excretion of 17betaestradiol 17beta-D-glucuronide is predominantly mediated by cMOAT/MRP2. Pharm Res 17: $546-552$.

Mottino AD, Cao J, Veggi LM, Crocenzi F, Roma MG, and Vore M (2002) Altered localization and activity of canalicular Mrp2 in estradiol-17beta-D-glucuronide-induced cholestasis. Hepatology 35:1409-1419.

Musey PI, Wright K, Preedy JRK, and Collins DC (1997) Formation and metabolism of steroid conjugates: effect of conjugation on excretion and tissue distribution, in Steroid Biochemistry Volume II (Hobkirk R ed) pp 81-132, CRC Press, Boca Raton, FL.

Pedersen JM, Matsson P, Bergström CA, Norinder U, Hoogstraate J, and Artursson P (2008) Prediction and identification of drug interactions with the human ATP-binding cassette transporter multidrug-resistance associated protein 2 (MRP2; ABCC2). J Med Chem 51:3275-3287.

Pfeifer ND, Yang K, and Brouwer KLR (2013) Hepatic basolateral efflux contributes significantly to rosuvastatin disposition I: characterization of basolateral versus biliary clearance using a novel protocol in sandwich-cultured hepatocytes. J Pharmacol Exp Ther 347:727-736.

Slikker W Jr, Vore M, Bailey JR, Meyers M, and Montgomery C (1983) Hepatotoxic effects of estradiol-17 beta-D-glucuronide in the rat and monkey. J Pharmacol Exp Ther 225:138-143.

Sohlenius-Sternbeck AK (2006) Determination of the hepatocellularity number for human, dog, rabbit, rat and mouse livers from protein concentration measurements. Toxicol In Vitro 20:1582-1586.

Stieger B, Fattinger K, Madon J, Kullak-Ublick GA, and Meier PJ (2000) Drug- and estrogeninduced cholestasis through inhibition of the hepatocellular bile salt export pump (Bsep) of rat liver. Gastroenterology 118:422-430.

Swift B, Pfeifer ND, and Brouwer KLR (2010) Sandwich-cultured hepatocytes: an in vitro model to evaluate hepatobiliary transporter-based drug interactions and hepatotoxicity. Drug Metab Rev 42:446-471.

Takikawa H, Sano N, Narita T, Uchida Y, Yamanaka M, Horie T, Mikami T, and Tagaya O (1991) Biliary excretion of bile acid conjugates in a hyperbilirubinemic mutant Sprague-Dawley rat. Hepatology 14:352-360.

Thakkar N, Slizgi JR, and Brouwer KLR (2017) Effect of liver disease on hepatic transporter expression and function. $J$ Pharm Sci 106:2282-2294.

Vallejo M, Briz O, Serrano MA, Monte MJ, and Marin JJ (2006) Potential role of trans-inhibition of the bile salt export pump by progesterone metabolites in the etiopathogenesis of intrahepatic cholestasis of pregnancy. J Hepatol 44:1150-1157.

Vildhede A, Wiśniewski JR, Norén A, Karlgren M, and Artursson P (2015) Comparative proteomic analysis of human liver tissue and isolated hepatocytes with a focus on proteins determining drug exposure. J Proteome Res 14:3305-3314.

Walker IA, Nelson-Piercy C, and Williamson C (2002) Role of bile acid measurement in pregnancy. Ann Clin Biochem 39:105-113.

Wang L, Prasad B, Salphati L, Chu X, Gupta A, Hop CE, Evers R, and Unadkat JD (2015) Interspecies variability in expression of hepatobiliary transporters across human, dog, monkey, and rat as determined by quantitative proteomics. Drug Metab Dispos 43:367-374.

Yang K, Pfeifer ND, Köck K, and Brouwer KLR (2015) Species differences in hepatobiliary disposition of taurocholic acid in human and rat sandwich-cultured hepatocytes: implications for drug-induced liver injury. J Pharmacol Exp Ther 353:415-423.

Zamek-Gliszczynski MJ, Hoffmaster KA, Nezasa K, Tallman MN, and Brouwer KLR (2006) Integration of hepatic drug transporters and phase II metabolizing enzymes: mechanisms of hepatic excretion of sulfate, glucuronide, and glutathione metabolites. Eur J Pharm Sci 27:447-486.

Zamek-Gliszczynski MJ, Kalvass JC, Pollack GM, and Brouwer KLR (2009) Relationship between drug/ metabolite exposure and impairment of excretory transport function. Drug Metab Dispos 37:386-390.

Zeng H, Liu G, Rea PA, and Kruh GD (2000) Transport of amphipathic anions by human multidrug resistance protein 3. Cancer Res 60:4779-4784.

Zollner G, Fickert P, Silbert D, Fuchsbichler A, Marschall HU, Zatloukal K, Denk H, and Trauner M (2003) Adaptive changes in hepatobiliary transporter expression in primary biliary cirrhosis. J Hepatol 38:717-727.

Zollner G, Fickert P, Zenz R, Fuchsbichler A, Stumptner C, Kenner L, Ferenci P, Stauber RE, Krejs GJ, Denk H, et al. (2001) Hepatobiliary transporter expression in percutaneous liver biopsies of patients with cholestatic liver diseases. Hepatology 33:633-646.

Zollner G, Wagner M, Fickert P, Silbert D, Gumhold J, Zatloukal K, Denk H, and Trauner M (2007) Expression of bile acid synthesis and detoxification enzymes and the alternative bile acid efflux pump MRP4 in patients with primary biliary cirrhosis. Liver Int 27:920-929.

Address correspondence to: Kim L.R. Brouwer, UNC Eshelman School of Pharmacy, University of North Carolina at Chapel Hill, CB \#7569, 3205 Kerr Hall, Chapel Hill, NC 27599-7569. E-mail: kbrouwer@unc.edu 